\title{
Pengeluaran Pariwisata dan Karakteristik Sosial Demografi Rumah Tangga di Provinsi Jawa Tengah
}

\author{
Sri Subanti ${ }^{1}$, Arif Rahman Hakim ${ }^{2}$ \\ ${ }^{1}$ Prodi Statistika, Grup Riset Statistika Ekonomi dan Bisnis, PUSPARI LPPM, Universitas Sebelas \\ Maret \\ ${ }^{2}$ Universitas Terbuka, Mahasiswa Pascasarjana Ilmu Ekonomi FEB Universitas Indonesia \\ ${ }^{1}$ srisubanti@staff.uns.ac.id, sri_subanti@yahoo.co.id \\ 2arhaqkm@gmail.com
}

\begin{abstract}
The study about tourism expenditure had been one of the important things in the formulation of tourism development, such as marketing analysis, strategies, and policies. Based on this condition, the purpose of our paper wants to know about the determinants of tourism expenditure at households level based on their demographic characteristics. The findings of this paper, (1) the important factors affecting household tourism expenditure are marital status, sex, household income per capita, education for heads of households, the length of study for household members in average, number of households, urban-rural, and industrial origin for head of household; (2) variables that are positively related to tourism expenditure are marital status, age, education, number of household, household income per capita, the length of study for household members in average, urban-rural, and home ownership. This paper suggest that the local governments should give an attention on households demographic characteristics to formulate the tourism marketing and the tourism policies.
\end{abstract}

Keywords : tourism expenditure, demographic characteristics, households

\section{Pendahuluan}

Studi tentang pengeluaran pariwisata telah menjadi salah satu hal penting dalam perumusan analisis pemasaran, strategi, dan kebijakan di bidang pariwisata. Kita dapat memulai studi ini dari siapa yang bersedia menghabiskan lebih banyak selama mereka tinggal di destinasi wisata. Selain itu, dengan pernyataan yang sama bahwa berapa banyak mereka akan menghabiskan lebih banyak uang untuk setiap tujuan wisata. Meskipun, beberapa literatur telah membahas tentang faktor-faktor penentu pengeluaran wisatawan pada tingkat rumah tangga, salah satunya karakteristik demografi [5]. Studi pengeluaran pariwisata dengan melibatkan karakteristik demografi menjadi penting, ini dikarenakan adanya evolusi pelaku wisata selama beberapa dekade terakhir dalam bentuk kemudahan melakukan aktivitas berwisata, sehingga mendorong pariwisata tidak hanya berdampak pada sektor tersebut tapi relevan meningkatkan pertumbuhan ekonomi di suatu negara [4].

Di Indonesia, dengan digulirkannya Rencana Induk Pengembangan Pariwisata Nasional 2020 - 2025, telah menjadikan sektor pariwisata sebagai salah satu elemen dari mesin pertumbuhan ekonomi. Salah satu caranya adalah mengembangkan Kawasan Pariwisata Strategis Nasional. Wilayah ini bukan hanya kawasan khusus yang diharapkan 
untuk meningkatkan ekonomi, sosial, dan budaya tetapi juga untuk memperhitungkan kelestarian alam dan lingkungan. Target utama telah ditetapkan oleh Kementerian Pariwisata dimana kontribusi sektor pariwisata akan meningkat hingga 8 persen terhadap produk domestik bruto (PDB). Berdasarkan data Biro Pusat Statistik, pada 2015, kontribusi sektor pariwisata yang diwakili oleh sektor akomodasi, makanan, dan minuman adalah sebesar 3 persen. Dari sisi penyerapan tenaga kerja, sektor ini dapat menciptakan 10,36 persen lapangan kerja dari total 114,8 juta atau setara dengan 11,89 juta pekerja di sektor pariwisata [3]. Menurut Badan Pusat Statistik Jawa Tengah (BPS Jawa Tengah), ditahun 2015, kontribusi sektor pariwisata yang diwakili oleh sektor akomodasi, makanan, dan minuman adalah sebesar 3,11 persen. Ini meningkat jika dibandingkan pada tahun 2010, kontribusi sektor ini sebesar 3,01 persen. Secara rata-rata sepanjang periode tersebut, sektor pariwisata telah berkonstribusi sebesar 3,05 persen terhadap produk domestik regional bruto (PDRB) di Provinsi Jawa Tengah.

Melalui uraian tersebut, paper ini menfokuskan pada sisi permintaan khususnya pengeluaran pariwisata yang dilakukan di tingkat rumah tangga, sehingga tujuannya adalah untuk mengetahui pengaruh karakteristik demografi pada pengeluaran pariwisata. Dengan kata lain, penerapan model regresi digunakan untuk menjelaskan hubungan antara variasi variabel karakteristik demografi terhadap pengeluaran pariwisata di Provinsi Jawa Tengah.

\section{Metode}

\subsection{Data}

Data dalam penelitian ini menggunakan data sosial ekonomi nasional (Susenas), tahun 2008. Data Susenas berisi data rumah tangga, data individu, dan data modul konsumsi. Jumlah rumah tangga yang terlibat berjumlah 6714 yang terbagi menjadi 2670 rumah tangga yang tinggal di perkotaan dan 4044 rumah tangga yang tinggal di pedesaan. Pengeluaran pariwisata rumah tangga didefinisikan sebagai pengeluaran yang digunakan untuk salon, salon kecantikan, penata rambut, klub kesehatan, dll; penginapan jauh dari rumah di perjalanan, dan perumahan untuk seseorang di sekolah; transportasi umum baik lokal maupun jarak jauh seperti bus dan kereta api; perhiasan dan jam tangan; ponsel; buku termasuk buku sekolah, koran dan majalah, mainan, permainan, dan hobi; dan TV kabel, hewan peliharaan dan dokter hewan, olahraga, country club, film, dan konser.

\subsection{Model dan Teknik Estimasi}

Model dalam tulisan ini dibangun dari model permintaan rumah tangga sebagai salah satu pelaku ekonomi. Dalam teori permintaan, rumah tangga diasumsikan 
mengkonsumsi sekelompok bundel konsumsi melalui konsumsi pariwisata dan konsumsi lainnya dengan kendala anggaran yang dihadapi oleh setiap rumah tangga. Perilaku rumah tangga sebagai agen ekonomi adalah mendapatkan kombinasi konsumsi optimum baik untuk pariwisata dan lainnya, sehingga memberikan utilitas maksimum bagi rumah tangga itu sendiri. Secara umum konsumsi pariwisata dapat dipengaruhi oleh pendapatan dan harga pariwisata, dimana hubungan konsumsi pariwisata berbanding lurus dengan pendapatan serta berbanding terbalik dengan harganya. Selain itu, ada faktor lain yang dapat mempengaruhi konsumsi pariwisata, diantaranya sosial demografi seperti jenis kelamin, pendidikan, lapangan usaha, dan sebagainya. Maka, model empiris yang digunakan dalam paper ini adalah sebagai berikut:

Toursimexp $_{i}=f\left(Y_{i}, W_{i}\right)$

Dimana, Tourismexp $\mathrm{p}_{\mathrm{i}}$ adalah pengeluaran pariwisata untuk rumah tangga i yang diproksi dari pengeluaran rumah tangga per kapita; $Y_{i}$ merupakan pendapatan rumah tangga per kapita; dan $\mathrm{W}$ merupakan kondisi sosial demografi rumah tangga.

Paper ini menggunakan teknik regresi berganda di mana parameter $\beta \mathrm{j}$ diestimasi dengan metode kuadrat terkecil $[\mathbf{2 ; 6 ; 7 ]}$. Kemudian, model regresi tersebut mempunyai sekumpulan variabel independen dan sebuah variabel dependen, model regresinya adalah sebagai berikut :

tourismexp $_{i}=\beta 0+\beta 1$ sex $_{i}+\beta 2$ age $_{i}+\beta 3$ age $^{\wedge} 2_{i}+\beta 4$ marstat $_{i}+\beta 5$ educ $_{i}+$ $\beta 6$ hhinc_capita $_{i}+\beta 7$ educ_hhmember ${ }_{i}+\beta 8$ numofhh $h_{i}+\beta 9$ numchild_15 $_{i}+$ $\beta 10$ urbanrural $_{i}+\beta 11$ houasset $_{i}+\beta 12$ hh_tourism $_{i}+\beta 13$ hh_agr $_{i}+$ $\beta 14 h h_{-}$ind $_{i}+\beta 15 h_{-} \operatorname{serv}_{i}+u_{i}$

Deskripsi variabel dalam model regresi tersaji dalam tabel 1.

Tabel 1. Deskripsi Variabel

\begin{tabular}{|c|c|}
\hline $\begin{array}{l}\text { Variabel Dependen } \\
\text { Tourismexp }\end{array}$ & $\begin{array}{c}\text { Deskripsi } \\
\text { pengeluaran pariwisata rumah tangga per kapita (dalam rupiah) }\end{array}$ \\
\hline Variabel Independen & Deskripsi \\
\hline Marstat & status menikah, $1=$ jika kepala rumah tangga menikah dan $0=$ lainnya \\
\hline Age & usia kepala rumah tangga (dalam tahun) \\
\hline $\operatorname{age}^{\wedge} 2$ & usia kepala rumah tangga kuadrat \\
\hline Sex & jenis kelamin, $1==$ jika kepala rumah tangga pria dan $0=$ lainnya \\
\hline
\end{tabular}




\begin{tabular}{l|l} 
Educ & $\begin{array}{l}\text { pendidikan terakhir yang ditamatkan kepala rumah tangga } \\
\text { educ_hhmember }\end{array}$ \\
hhicn_capita & $\begin{array}{l}\text { rerata pendidikan terkahir yang ditamatkan dalam oleh anggota rumah tangga } \\
\text { pendapatan rumah tangga perkapita } \\
\text { Numofhh }\end{array}$ \\
numchild_15 & $\begin{array}{l}\text { jumlah anggota rumah tangga } \\
1=\text { jika kepala rumah tangga tinggal di kota dan } 0=\text { lainnya } \\
\text { Urbanrural }\end{array}$ \\
Houasset & $\begin{array}{l}1=\text { jika rumah yang ditempati milik sendiri dan } 0=\text { lainnya } \\
1=\text { jika kepala rumah tangga bekerja di sektor pertanian dan } 0=\text { lainnya } \\
\text { hh_tourism }\end{array}$ \\
hh_agr & $\begin{array}{l}1=\text { jika kepala rumah tangga bekerja di sektor industri dan } 0=\text { lainnya } \\
1=\text { jika kepala rumah tangga bekerja di sektor jasa dan } 0=\text { lainnya }\end{array}$ \\
hh_ind & hh_serv
\end{tabular}

\section{Hasil dan Pembahasan}

Bagian berikut akan menyajikan hasil pengolahan data yang terdiri dari profil demografi dan estimasi regresi sebagaimana tersaji dalam tabel 2 dan tabel 3 .

Tabel 2. Profil Demografi

\begin{tabular}{|c|c|c|c|c|c|}
\hline Karakteristik & Frek. & Persentase & Karakteristik & Frek. & Persentase \\
\hline Jenis Kelamin & & & Tempat Tinggal & & \\
\hline Pria & 5864 & 87.34 & Desa & 4044 & 60.23 \\
\hline Wanita & 850 & 12.66 & Kota & 2670 & 39.77 \\
\hline Usia & & & Pendidikan & & \\
\hline $16-25$ & 154 & 2.29 & SMP atau dibawah & 4851 & 81.03 \\
\hline $26-35$ & 1109 & 16.52 & SMU & 1005 & 14.97 \\
\hline $36-45$ & 1965 & 29.27 & Diploma & 77 & 1.15 \\
\hline $46-55$ & 1945 & 28.97 & Sarjana atau diatas & 191 & 2.85 \\
\hline$>55$ & 1541 & 22.95 & Aset Rumah & & \\
\hline Status Menikah & & & Milik Sendiri & 5897 & 87.83 \\
\hline Lainnya & 961 & 14.31 & Lainnya & 817 & 12.17 \\
\hline Menikah & 5753 & 85.69 & & & \\
\hline
\end{tabular}

Tabel 2. Proporsi kepala rumah tangga berjenis kelamin pria (87.34\%) lebih tinggi dibandingkan kepala rumah tangga berjenis kelamin wanita. Mayoritas kepala rumah tangga berstatus menikah sebesar $85.69 \%$ dibandingkan lainnya sebesar $14.31 \%$. kelompok usia kepala rumah tangga terdistribusi cukup merata kecuali untuk kelompok usia dibawah 
25 tahun. Mayoritas kepala rumah tangga menamatkan pendidikan sekolah menengah pertama atau dibawahnya, meskipun ada juga kepala rumah tangga yang tamat diploma atau universitas. Kepala rumah tangga yang tamat sekolah menengah pertama atau dibawahnya sebesar $81.03 \%$, diikuti $1.15 \%$ untuk kepala rumah tangga yang tamat diploma, dan $2.85 \%$ untuk kepala rumah tangga yang tamat sarjana atau diatasnya. Mayoritas kepala rumah tangga tinggal di pedesaan sebesar $60.23 \%$, sisanya $39.77 \%$ tinggal di perkotaan. Aset rumah telah dimiliki mayoritas kepala rumah tangga yaitu sebesar $87.83 \%$.

Berdasarkan tabel 3, dapat diketahui bahwa pengeluaran pariwisata dengan dengan kepala rumah tangga pria laki-laki adalah 43763 rupiah lebih kecil daripada kepala rumah tangga perempuan. Kemudian, usia memiliki hubungan non linier (terbalik) dengan pengeluaran pariwisata. Dari temuan ini, kita dapat mengatakan bahwa usia antara 16 dan 36 tahun berasosiasi positif dengan pengeluaran pariwisata atau ada peningkatan untuk pengeluaran pariwisata; tetapi lebih dari 36 tahun berasosiasi negatif terhadap pengeluaran pariwisata atau ada penurunan pengeluaran pariwisata [1]. Penjelasan lebih lanjut, usia antara 16 dan 36 tahun dapat diklasifikasikan sebagai orang muda dan usia menengah, mereka menganggap kegiatan pariwisata menjadi bagian dari gaya hidup mereka dan bahwa liburan menjadi perhatian ekstra bagi kepala rumah tangga yang berusia dalam rentang usia ini.

Variabel status perkawinan, hasil menunjukkan bahwa pengeluaran pariwisata rumah tangga yang menikah adalah 41127 rupiah lebih tinggi dibandingkan lainnya. Ini dianggap sebagai faktor penentu perilaku belanja wisatawan. Dalam kerangka kegiatan pariwisata, kedua pasangan (suami dan istri) adalah pelengkap dan non subtitusional $[\mathbf{4} ; \mathbf{5}]$. Seperti yang diharapkan dari teori ekonomi bahwa rumah tangga berpenghasilan tinggi menghabiskan lebih banyak uang untuk pengeluaran pariwisata mereka daripada rumah tangga berpenghasilan rendah. Karena pendapatan adalah kendala anggaran rumah tangga yang menentukan alokasi belanja pariwisata rumah tangga dan menjadi salah satu penentu dalam memaksimalkan utilitas mereka $[\mathbf{1} ; \mathbf{4}]$.

Tabel 3. Hasil Estimasi Regresi

\begin{tabular}{llllll}
\hline \multicolumn{5}{c}{ Variabel Dependen : tourismexp } \\
\hline \multirow{2}{*}{ Variabel Independen } & \multicolumn{3}{c}{ Model 1 } & \multicolumn{2}{c}{ Model 2 } \\
\cline { 2 - 5 } & Coef. & Std. Err. & Sign. & Coef. & Std. Err. Sign. \\
\hline
\end{tabular}



Vol. 1 No.1 May 2018

\begin{tabular}{|c|c|c|c|c|c|c|}
\hline$\overline{\mathrm{Sex}}$ & -43763.11 & 21404.73 & *** & $2-44730.00$ & 21525.39 & *** \\
\hline Age & 787.47 & 2502.82 & & 700.97 & 2497.33 & \\
\hline $\operatorname{age}^{\wedge} 2$ & -10.97 & 28.31 & & -10.18 & 28.24 & \\
\hline Marstat & 41127.43 & 18617.76 & $* *$ & 41509.40 & 18693.24 & $* *$ \\
\hline Educ & 5163.06 & 2271.08 & $* *$ & 5089.72 & 2269.87 & $* *$ \\
\hline hhicn_capita & 0.086 & 0.04 & $* *$ & 0.086 & 0.04 & $* *$ \\
\hline educ_hhmember & 8764.60 & 3502.91 & $* * *$ & 8810.09 & 3513.25 & $* * *$ \\
\hline numofhh & 16410.95 & 5482.47 & $* * *$ & 16400.62 & 5485.70 & $* * *$ \\
\hline numchild_15 & -5796.51 & 3830.06 & & -5737.12 & 3840.09 & \\
\hline urbanrural & 20215.94 & 8692.83 & $* *$ & 20273.32 & 8703.42 & $* *$ \\
\hline houasset & 16232.72 & 12032.97 & & 16066.74 & 12006.87 & \\
\hline hh_tourism & & & & -147305.10 & 64250.02 & $* *$ \\
\hline hh_agr & -131318.50 & 64815.69 & $* *$ & -128261.40 & 64578.72 & $* *$ \\
\hline hh_ind & -142408.90 & 66664.25 & $* *$ & -139353.70 & 66396.99 & $* *$ \\
\hline hh_serv & -130735.60 & 62640.49 & $* *$ & -126924.50 & 62425.96 & $* *$ \\
\hline Number of obs & & 3308 & & & 3308 & \\
\hline $\mathrm{F}-\mathrm{Stat}$ & & 76.440 & & & 73.520 & \\
\hline Prob $>F$ & & 0.000 & & & 0.000 & \\
\hline R-squared & & 0.133 & & & 0.133 & \\
\hline$*=$ sign. Alpha $10 \%$ & \multicolumn{3}{|c|}{$* *=$ sign. Alpha 5\% } & \multicolumn{3}{|c|}{$* * *=$ sign. Alpha $1 \%$} \\
\hline
\end{tabular}

Variabel pendidikan yang diwakili oleh lamanya sekolah, ditemukan bahwa semakin tinggi pendidikan kepala rumah tangga cenderung meningkatkan pengeluaran pariwisata sebesar 5163 rupiah. Hubungan positif menunjukkan fakta bagi orang-orang dengan tingkat pendidikan yang lebih tinggi cenderung mendapatkan pekerjaan yang memberikan upah yang lebih tinggi pula, sehingga memungkinkan mereka untuk mengalokasikan anggaran berwisata yang lebih tinggi [5]. Variabel aset perumahan berhubungan positif dengan pengeluaran pariwisata. Ini menunjukkan bahwa kepala rumah tangga yang telah memiliki rumah dianggap telah memenuhi kebutuhan dasar mereka, sehingga rumah tangga dapat mengalokasikan anggaran lain salah satunya untuk pengeluaran pariwisata. 


\section{Kesimpulan}

Temuan paper ini, (1) determinan yang signifikan mempengaruhi pengeluaran pariwisata adalah status pernikahan, jenis kelamin, pendapatan rumah tangga per kapita, pendidikan kepala rumah tangga, rerata pendidikan anggota rumah tangga, jumlah anggota rumah tangga, status tinggal, dan lapangan usaha pekerjaan kepala rumah tangga. (2) variabel yang berhubungan positif terhadap pengeluaran pariwisata adalah status pernikahan, usia, pendidikan, jumlah anggota kepala rumah tangga, pendapatan per kapita, rerata usia anggota rumah tangga, status tinggal, dan kepemilikan rumah. Saran paper ini, pemerintah daerah perlu mempertimbangkan karakteristik demografi dalam merumuskan pemasaran dan kebijakan pariwisata.

\section{Daftar Pustaka}

[1] C. Thrane, "The Determinant of Norwegians Summer Tourism Expenditure : Foreign and Domestic Trips", Tourism Economics, Vol 22 (1), pp. 31 - 46, 2016.

[2] D. Gujarati, and C. D. Porter, Basic Econometric $5^{\text {th }} E d$, New York : McGraw - Hill, 2009.

[3] D.Handayani, and S. Djamaluddin, "The Propensity of Household to Go on Vacation, Indonesia", Advanced in Economics, Business, and Management Research, Vol 28, pp. $196-200,2017$.

[4] J.G. Brida, and R. Scuderi, "Determinant of Tourist Expenditure : a Review of Microeconometric Models", MPRA Paper, No. 38468, Posted 30 April 2012.

[5] J.L. Nicolau, and J.M Francisko, "Simultaeous Analysis of the Decision to Go on Holiday and Vacation Expenditures", (2007) [Online] https://www.researchgate.net/profile/Juan_Nicolau2/publication/28202453_Simultan eous_analysis_of_the_decisions_to_go_on_holiday_and_vacation_expenditures/link s/0fcfd505b20312cc4b000000/Simultaneous-analysis-of-the-decisions-to-go-onholiday-and-vacation-expenditures.pdf

[6] M. Ekananda, Basic Econometrics for Research on Economics, Social, and Business, Jakarta : Mitra Wacana Media, 2014.

[7] N.D. Nachrowi, and H. Usman, Popular Approach and Econometrics Practices for Economics and Finance Analysis, Jakarta : Faculty of Economics and Business Universitas Indonesia, 2006. 